\title{
Trophic niche partitioning between two native and two exotic carnivores in SW Portugal
}

\author{
Maria João Santos, Bruno Miguel Pinto and Margarida Santos-Reis
}

Santos, M. J., Pinto, B. M. and Santos-Reis, M. Trophic niche partitioning between two native and two exotic carnivores in SW Portugal. - Web Ecol. 7: 53-62.

\begin{abstract}
The introduction of exotic species is one of the most pervasive consequences of the increased human mobility. The most known negative effects are the decrease or extinction of natives. The common-genet, Genetta genetta, and the Egyptian mongoose, Herpestes ichneumon, were introduced in the Iberian Peninsula in the 15th and 19th centuries, respectively. The competitive exclusion principle defines that two ecologically similar species cannot coexist. Thus, some degree of partitioning has to occur in species realized niche, which can occur at the trophic level. To test this hypothesis of partitioning we compared the diet of these two exotic species with that of two native species (stone marten, Martes foina, and red fox, Vulpes vulpes). The results show a high degree of overlap (>45\%) between the diets of species similar in their feeding strategies (arboreal and ground feeding). Nonetheless, at the finer scale of prey consumed at the species level some differences are found between the native and exotic species. These results suggest that if coexistence is due to trophic niche partitioning it only occurs at the level of the consumed species. However, coexistence may also be due to a combination of different strategies (home-range size, time and space use) that structured the different realized niches of each species.
\end{abstract}

M. J. Santos, B. M. Pinto and M. Santos-Reis (mmreis@fc.ul.pt), Univ. de Lisboa, Centro de Biologia Ambiental, Faculdade de Ciências, Ed. C2, $3^{\circ}$ Piso, Campo Grande, PT-1749016 Lisboa, Portugal.

During past centuries, the increases of human mobility and activities (e.g. agriculture, aquaculture, recreation and transportation) have caused the introduction of species to different geographic areas (Sutherland 1998, Kolar and Lodge 2001). Species are termed as exotic or non-native when they have not evolved in a given geographic area, and have been accidentally introduced or brought for a specific purpose (Sutherland 1998). Exotic species success is usually measured by the extinction of native species and the potential to alter the environment or pose serious threats to human health (Primack 1998). Smallwood (1994) has shown that birds and mammals site invasibility in Californian habitats is directly related to the degree of human dis- turbance at a site when exotics arrive, with native mammals' richer areas being less prompt for exotic success.

The common genet Genetta genetta and the Egyptian mongoose Herpestes ichneumon are two species of African mesocarnivores, introduced in the Iberian Peninsula (Dobson 1998). The earliest remains of common genet in Europe date to the Middle Ages (Dobson 1998) and the first records of Egyptian mongoose are from the latest 1800s (Delibes 1982). Presently, the common genet is distributed throughout the Iberian Peninsula and south of France (Livet and Roeder 1987, Calzada 2002), whereas the Egyptian mongoose is limited to the SW of the Iberian Peninsula (Delibes 1982, Borralho et al. 1996, Palomares 2002). 
The competitive exclusion principle states that two species with similar ecology cannot live together in the same place (Hardin 1960). Considering that these two exotic species are generalist carnivores, which coexist and potentially compete with native species, the goal of this study was to investigate if the partitioning in species realized niche occurs at the trophic level. In order to test this hypothesis, we studied the diet of two native carnivores: red fox, Vulpes vulpes, and stone marten, Martes foina, and compared it with the diet of that two introduced species. The choice of these two native carnivores, within the local community of carnivores (Santos-Reis et al. 1999), can be justified by the fact that they are the ones that most likely would be affected by strong competition with the genet and the mongoose because have similar body mass and sizes (Rosalino et al. 2005). Moreover, they share similar ecoethological behaviours, with the Egyptian mongoose and the red fox being more terrestrial and the genet and stone marten more arboreal. It can then be predicted that in sympatric areas, the native and exotic species depend on similar prey types and have approximate diets. A high trophic niche overlap between red fox/Egyptian mongoose and genet/stone marten would also be expected as a consequence of their morphological and eco-ethological resemblance.

\section{Material and methods}

\section{Study area}

The study was carried out in a $35 \mathrm{~km}^{2}$ area located in Grândola Mountain (Alentejo, SW Portugal). This area is mostly cork oak woodland -"montado", a typical Mediterranean ecosystem common in southern Portugal. Cork oak woodlands, Quercus suber, with holm oaks, Q. ilex, and Lusitanian oaks, $Q$. faginea, dominate the land cover of the area. There are some patches of eucalyptus, Eucalyptus globulus, and maritime pine, Pinus pinaster. Common alder, Alnus glutinosa, black willow, Salix nigra, and common sallow, Salix atrocinerea, are found in riparian areas. The understory is dominated by rock-roses, Cistus salvifolius, and C. ladanifer, lavender, Lavandula luisieri, and strawberry tree, Arbutus unedo, with patches of blackberry bushes, Rubus spp. Small orchards with pear, Pyrus bourgaeana, fig, Ficus carica, loquat, Eriobotrya japonica trees, and olive, Olea europaea, are found scattered throughout the area. The climate is Mediterranean with some Atlantic influence, and precipitation levels assume mean annual values of $500 \mathrm{~mm}$. The altitude ranges from 159 to $238 \mathrm{~m}$, with few permanent or temporary streams (Santos-Reis and Correia 1999). Human activity occurs in a small village and isolated farmhouses, but their effects are extended to the areas where cork and livestock are produced. Hunting and logging are occasional.

\section{Sampling methods}

For the red fox, Egyptian mongoose and stone marten, sampling was based on scat collection along three different linear pedestrian transects, with $6.5 \mathrm{~km}$ of length each. Due to the marking behaviour of the common genet (Livet and Roeder 1987) and stone marten (Libois and Waechter 1991), radio tracked individuals of both species provided the location of latrines where scats were also collected (Santos-Reis et al. 2004). The first scats found in transects and latrines were destroyed, to allow for a correct dating. Scat collection was conducted monthly by the same two observers, from January to November of 1997.

We collected and identified 380 scats: 195 scats of red fox, 75 scats of common-genet, 58 scats of stone-marten and 52 scats of Egyptian mongoose. Scat identification was based on its characteristics (length, diameter, odour, and morphology; Kendall et al. 1994, Sadlier et al. 2004) and crosschecked by other specialists. Errors in the identification of scats were minimised using more than one diagnostic feature and the exclusion of scats with doubtful identification (Ray and Sunquist 2001). The sample size was considered large enough to characterize the four species' diet, because the number of prey items in each category reached an asymptote in the cumulative number of identified items $\left(\mathrm{n}_{\text {red fox }}=26, \mathrm{n}_{\text {common genet }}=24, \mathrm{n}_{\text {stone marten }}=30\right.$, and $\left.\mathrm{n}_{\text {Egyptian mongoose }}=31\right)$.

Scats were dried in an oven at $50^{\circ} \mathrm{C}$, washed in a $1 \times 1$ $\mathrm{mm}$ fine-meshed sieve, and prey items were first separated and classified in six broad categories: mammals, birds, reptiles, arthropods (insects, chilopods, crustaceans and arachnids), fruits and other plant material. Each food item was then dried, weighed on a scale to the nearest $0.0001 \mathrm{~g}$, and identified to the species level, whenever possible, based on previous works (Gama 1957, Keller 1978, 1980, 1981, Madureira and Ramalhinho 1981, Debrot et al. 1982, Brom 1986, Chinery 1986), expert knowledge, and reference collections.

Minimum number of individuals was counted through distinctive features (e.g. jaws, bones, seeds). When nonquantifiable remains from each food item were found, the minimum number of individuals was assumed to be equal to 1 . Each food item was quantified in relative frequency of occurrence and of biomass. Relative frequency of occurrence (RFO) is the proportion of the total number of individuals that made up each food class. Frequency of biomass (FBiom) is the proportion of the total consumed biomass of each class.

Biomass was assessed by multiplying the minimum number of individuals of each item by its correction factor (insectivores and small rodents $=23$, lagomorphs $=50$, goat $=118$, reptiles and amphibians $=29.5$, insects, crayfish and molluscs $=5$, fruit seed and other plant material $=14$; Jedrzejewska and Jedrzejewski 1998). We used the correction factors available in the literature for stone marten because all four carnivores consumed similar frequency of the 
different prey items (Jedrzejewska and Jedrzejewski 1998). All the items were converted into biomass, except the plant (non-fruit) material, which does not contribute with significant energetic value in the diet for these carnivores (Libois and Waechter 1991) and was excluded from further analysis.

Prey availability estimation was directed towards small mammals, the main prey items identified by previous studies on the diet of these species (Palomares and Delibes 1991). Thus, a seasonal trapping scheme was established to estimate the relative abundance of wood mouse, Apodemus sylvaticus, house mouse, Mus spretus, black rats, Rattus rattus, and white toothed shrew, Crocidura russula. One hundred Sherman live-traps were set each season (winter, spring, summer and autumn) during 5 nights, in the three most represented habitats of the study area: cork oak woodlands with understorey; cork oak woodlands with pasture and riparian vegetation. Captured small mammals were identified, weighted, individually-marked and released in the same area of capture to avoid disturbance to animal behaviour.

\section{Statistical analysis}

Two different levels of food items were considered: first, based on broad taxonomic food categories; second, family categories of the different food categories (Krebs 1989). The reliability of scat sample size was assessed for each species by plotting accumulation curves for prey species (Ray and Sunquist 2001).

Comparisons between species trophic niche composition were performed using ANOVA (F) and Tukey HSD post hoc tests (significance level 0.05 ) with transformed data for both levels of classification (food categories and family) (Zar 1999). Food item's availability and use were compared using the Pearson's correlation coefficient (r). Trophic niche breadth was measured using Levins' index, ranging from 1 to n, i.e. specialist to generalist food habits, respectively (Levins 1968). Trophic niche overlap was calculated using Pianka's index (for the food categories and families), varying from 0 (exclusive food niches) to 1 (complete dietary overlap) (Krebs 1989). All calculations were performed in Microsoft Excel 2003, SPSS for Windows, release 11.5.0 (SPSS Inc.) and Statistica ver. 5 software.

\section{Results}

\section{Diet of carnivores}

The most common food items consumed by the four studied species were insects, fruits and mammals (Table 1). Among the native species, the stone marten had the highest intake of fruits (FBiom=0.568), whereas the red fox showed higher consumption of mammals (FBiom=0.704). The long-established species had different feeding strategies, with the common-genet consuming similar values of mammals (FBiom $=0.273)$, fruits $(\mathrm{FBiom}=0.263)$ and arthropods (FBiom $=0.380$ ), whereas the Egyptian mongoose had a higher consumption of mammals (FBiom $=0.493$; Table 1 ).

For all species, mammals made up the largest portion of the diet, reaching $20 \%$ of the total biomass consumed (Table 1). The red fox was the species that consumed the greatest biomass proportion of this vertebrate class, and most mammal species $(n=8)$. There were significant differences in the proportion of mammals consumed by all the studied species ( $\mathrm{F}=8.07, \mathrm{p}<0.001)$; the red fox consumed significantly more mammals than the stone marten (ANOVA, post-hoc Tukey, $\mathrm{p}<0.001$ ) and the common genet (ANOVA, post-hoc Tukey, $\mathrm{p}=0.02$ ), whereas the differences for the Egyptian mongoose and all the other species were not significant. Red foxes and Egyptian mongooses fed on a greater number of mammals, often consuming larger species, such as Lagomorphs and rats Rattus spp., which were not consumed by common-genets and stone martens (Fig. 1).

Table 1. Relative frequency of occurrence and frequency of biomass of food items consumed by common genets, Genetta genetta, Egyptian mongooses, Herpestes ichneumon, stone martens, Martes foina, and red foxes, Vulpes vulpes, at Grândola mountain (SW Portugal). RFO=Relative frequency of occurrence; FBiom=Frequency of biomass.

\begin{tabular}{lcccccccc}
\hline \multirow{2}{*}{ Food items } & \multicolumn{2}{c}{ Genetta genetta } & \multicolumn{2}{c}{ Herpestes ichneumon } & \multicolumn{2}{c}{ Martes foina } & \multicolumn{2}{c}{ Vulpes vulpes } \\
& RFO & FBiom & RFO & FBiom & RFO & FBiom & RFO & FBiom \\
\hline Mammals & 0.037 & 0.273 & 0.046 & 0.493 & 0.021 & 0.220 & 0.041 & 0.704 \\
Birds & 0.008 & 0.084 & 0.007 & 0.149 & 0.003 & 0.035 & 0.005 & 0.111 \\
Reptiles & - & - & 0.002 & - & - & - & - & - \\
Insecta & 0.755 & 0.12 & 0.848 & 0.075 & 0.818 & 0.126 & 0.912 & 0.115 \\
Chilopoda & 0.029 & 0.013 & 0.020 & 0.012 & 0.017 & 0.020 & 0.008 & 0.005 \\
Crustacea & 0.034 & 0.240 & - & - & 0.003 & 0.030 & 0.0001 & 0.004 \\
Aracnida & 0.026 & 0.007 & 0.010 & 0.005 & 0.014 & 0.001 & 0.006 & 0.001 \\
Fruits & 0.111 & 0.263 & 0.066 & 0.266 & 0.123 & 0.568 & 0.027 & 0.060 \\
\hline
\end{tabular}




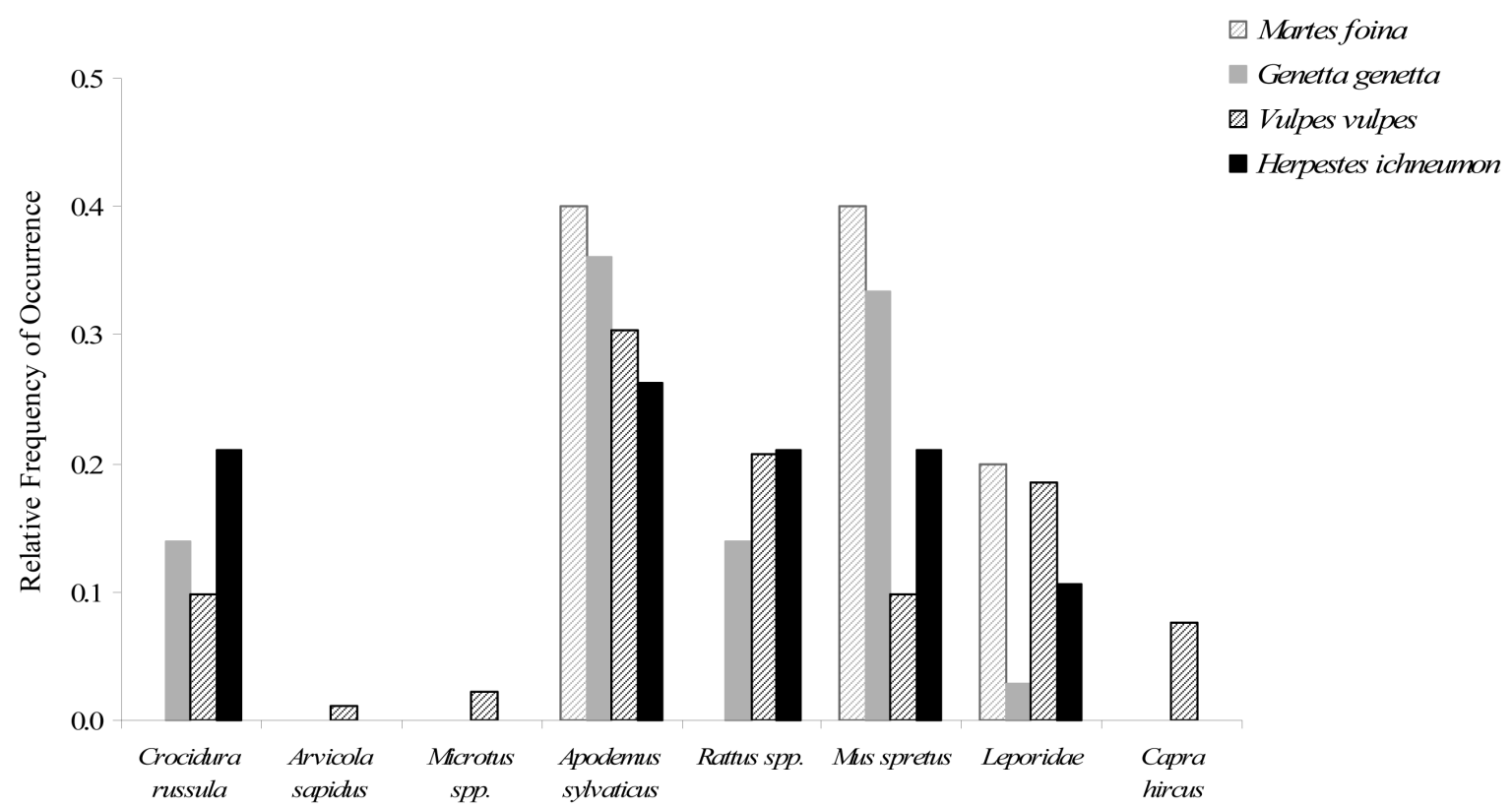

Fig. 1. Relative frequency of occurrence of mammal species consumed by four carnivores in SW Portugal (order Insectivora: family Soricidae: Crocidura russula; order Rodentia: family Muridae: Arvicola sapidus, Microtus spp., Apodemus sylvaticus, Mus spretus, and Rattus spp.; and order Lagomorpha: family Leporidae).

The four studied species consumed birds, mainly passerines $(82.8 \%$ of biomass of consumed birds), with no significant differences between each other $(\mathrm{F}=0.883$, $\mathrm{p}=0.4)$. Galliformes were the most consumed birds in red fox and Egyptian mongoose diets. Insects were the most abundant arthropods in the analysed scats. All carnivores consumed a relatively large number of beetles (Coleoptera) and crickets (Orthoptera), and had a similar diversity of insect families (Fig. 2). We found significant differences in the consumption of arthropods between the four studied species $(\mathrm{F}=4.34, \mathrm{p}<0.01)$. The red fox consumed significantly fewer arthropods than the common genet (ANOVA, Tukey-test $\mathrm{p}<0.01)$. Other differences in arthropod abundance and diversity in the diet were not significant. Crustaceans were represented in the diet of the four carnivore species by the introduced Louisiana crayfish Procambarus clarkii, which reached a maximum value of $24 \%$ of biomass frequency for the common-genet (Table 1). Although this prey was also consumed by the stone marten and red fox, its frequency was much lower.

All species consumed a high proportion of fruits, with the exception of the red fox. The most eaten fruit item were pears, which accounted for more than $70 \%$ of all consumed fruits in the scats of Egyptian mongoose and stone marten (Fig. 3). Figs also assumed a high importance on the diet of the common genet ( $30 \%$ of the scats). The consumption of fruits was significantly different between the species $(\mathrm{F}=5.85, \mathrm{p}<0.001)$, with the stone marten reveal- ing a higher frugivory than the red fox (ANOVA, post-hoc Tukey, $\mathrm{p}<0.001$ ) and the common genet (ANOVA, posthoc Tukey, $\mathrm{p}=0.02$ ).

\section{Consumed versus available prey items}

The different prey items were not consumed accordingly to availability. Only the Egyptian mongoose and the stone marten showed a higher consumption of Muridae (Mus spp., Apodemus spp. and Rattus spp.) than available throughout the year, as reflected by a negative $r$ value $(r=-$ 0.58) (Fig. 4). On the other hand, a more opportunistic feeding behaviour is found in the common genet with a high correspondence between the consumed and available Soricidae ( $\mathrm{r}=0.75)$ and Muridae ( $\mathrm{r}=0.58$; Fig. 4).

\section{Trophic niche breadth and overlap}

The trophic resource niche was similar between native and long-established species. There were no significant differences in interspecific prey compositions ( $p>0.05$ ). However, niche breadth was wider in the long-established species than the native ones. According to Levins' index, the genet had the wider trophic niche $(\mathrm{B}=0.285)$, followed by Egyptian mongoose $(B=0.272)$, stone marten $(B=0.189)$ and red fox $(B=0.124)$. 


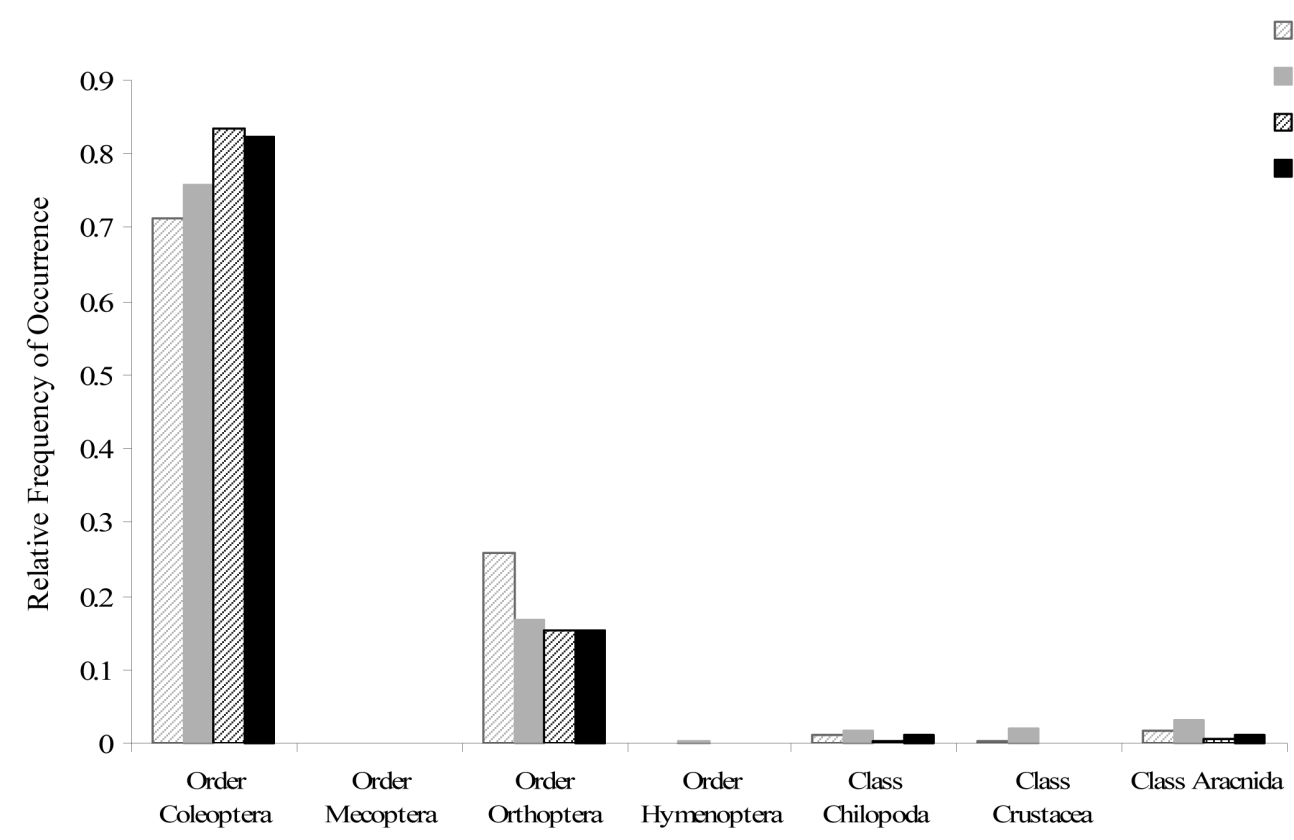

Fig. 2. Relative frequency of occurrence of arthropods consumed by four carnivores in SW Portugal (Insecta: order Coleoptera, order Mecoptera, order Orthoptera, and order Hymenoptera; Chilopoda, Crustacea and Aracnida) consumed by common genets, Egyptian mongooses, stone martens and red foxes.

We found a high degree of niche overlap between the species trophic niche. All the species overlapped their diets over $45 \%$ of consumed items (Table 2). Pianka's index value was higher for the overlap between the red fox and the
Egyptian mongoose $(\mathrm{O}=0.955)$, whereas stone marten and common genet had a relatively lower overlap $(\mathrm{O}=0.755)$. The lowest overlap is found between the two native species $(\mathrm{O}=0.467)$.

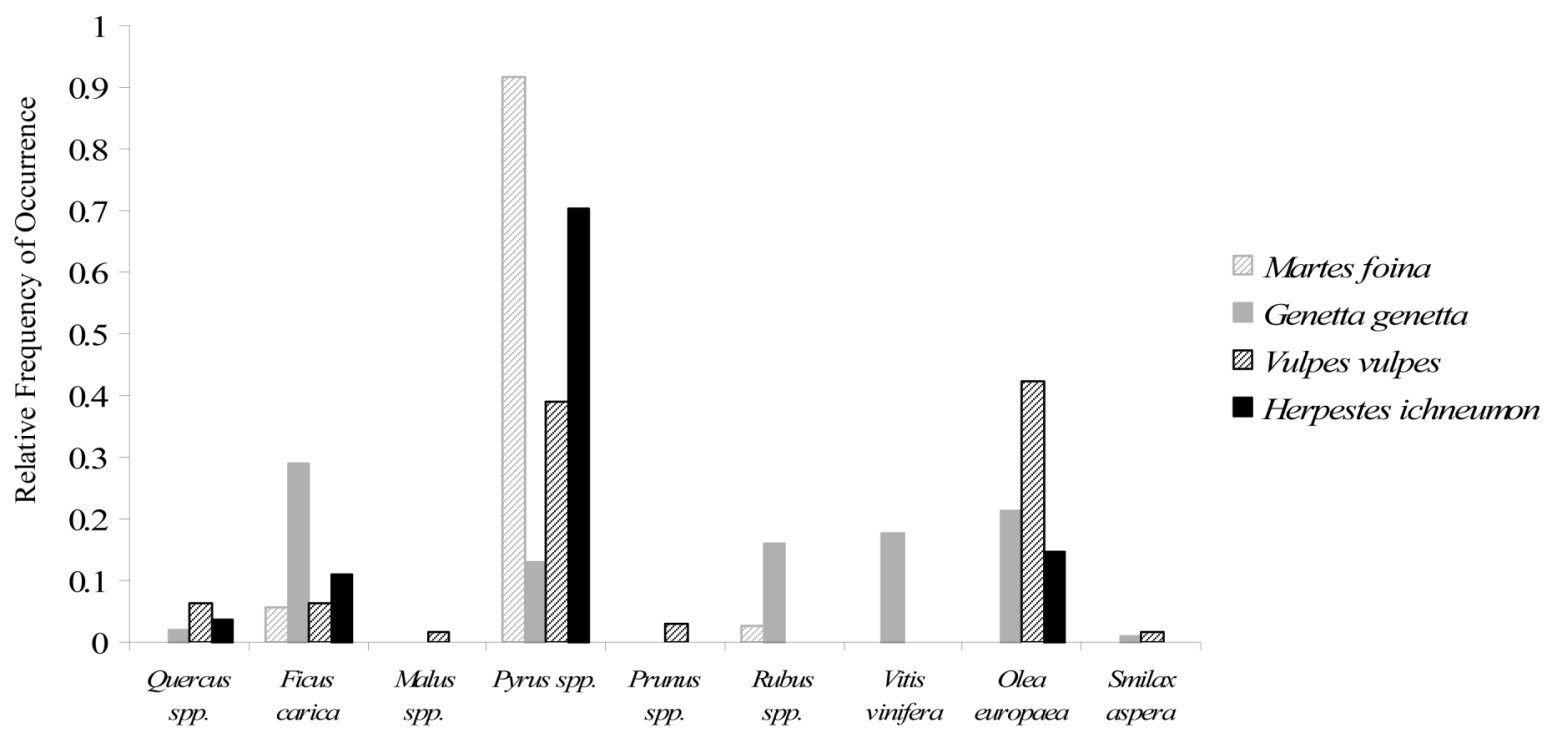

Fig. 3. Relative frequency of occurrence of fruits consumed by four carnivores in SW Portugal (family Fagaceae: Quercus spp.; family Moraceae: Ficus carica; family Rosaceae: Malus spp., Pyrus spp., Prunus spp., Rubus ulmifolius, family Vitaceae: Vitis vinifera; family Oleaceae: Olea europaea; family Smilacaceae: Smilax aspera). 

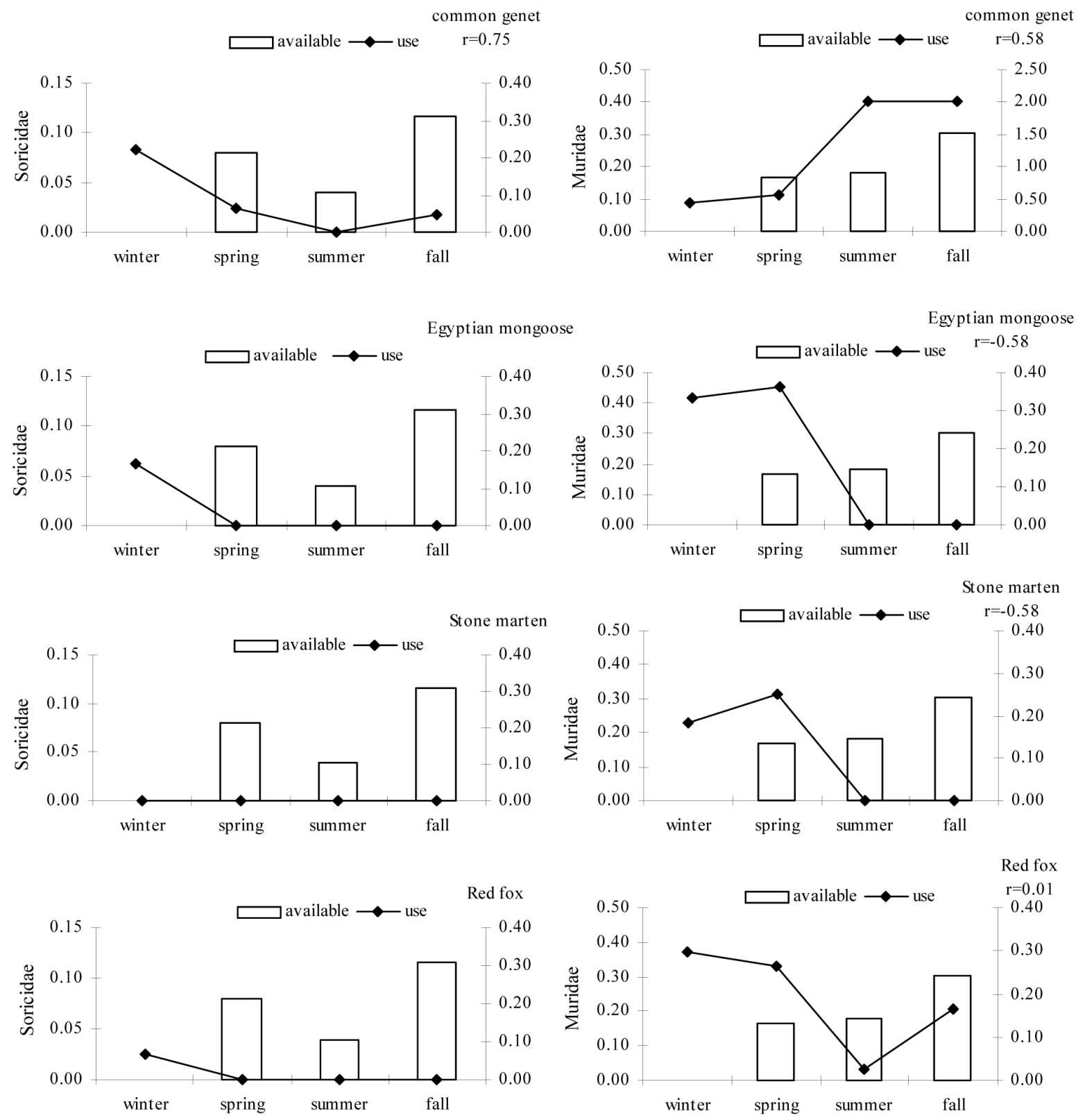

Fig. 4. Seasonal variation of use vs availability of Soricidae (Crocidura russula) and Muridae (Apodemus sylvaticus, Mus spretus, and Rattus rattus) in the diet of common genets, Egyptian mongooses, stone martens and red foxes in the study area ( $\mathrm{r}$ - correlation coefficients; when availability and consumed data were not coincident estimates of $\mathrm{r}$ were not attained; ${ }^{*}$ - denotes significance at $\mathrm{p}<0.05 ;{ }^{* *}$ denotes significance at $\mathrm{p}<0.01)$.

\section{Discussion}

In Grândola mountain (SW Portugal), native and exotic species share the available food resources and have coexisted for hundreds of years. The diet of the four species has a high degree of overlap in the most consumed items (mammals, fruits and insects), with a clear distinction in diet between arboreal and terrestrial species, and no differences were found between native and exotic species. 
Table 2. Pianka's trophic niche overlap in pair-wise comparisons between the study species ( 0 - no overlap; 1 - complete overlap in trophic resources).

\begin{tabular}{lccc}
\hline & Genetta genetta & Martes foina & Herpestes ichneumon \\
\hline Martes foina & 0.775 & & \\
Herpestes ichneumon & 0.843 & 0.694 & 0.955 \\
Vulpes vulpes & 0.743 & 0.467 & \\
\hline
\end{tabular}

\section{Diet of carnivores}

The studied native carnivore species of southern Iberia have different trophic niche composition when compared to the North European niche structure. In fact, both native species show a plastic behaviour in prey selection, which changes accordingly with latitude. The stone marten increases its diet diversity in southern Europe when compared with northern Europe, where it feeds on high energy prey - mammals and birds (Denmark: Rasmussen and Madsen 1985; Poland: Goszczynski 1986; Romania: Romanowski and Lesínski 1991; Hungary: Lanszki et al. 1999). In southern latitudes the stone marten has a richer diet, including eggs and fruits (France: Waechter 1975, Libois and Waechter 1991), and in the Mediterranean region, mammals, fruits and invertebrates are equally consumed (Italy: Serafini and Lovari 1993; Spain: Delibes 1978, Alegre et al. 1991, Ruiz-Olmo and Palazon 1993, Padial et al. 2002; Portugal: Carvalho and Gomes 2004). Our results also corroborate this increased dietary richness in diet. The red fox, however, has been considered to be one of the most generalist carnivores in Europe (Sweden: Storch et al. 1990; Poland: Goszczynski 1974, 1986; Hungary: Lanszki et al. 1999; France: Artois et al. 1982; Artois 1989; Italy: Serafini and Lovari 1993) and in Mediterranean habitats, where the red fox has been described as feeding on a large range of prey (Italy: Serafini and Lovari 1993; Spain: Calviño et al. 1984, Padial et al. 2002). However, our data contradict this pattern, with the red fox being the least generalist of the four species studied, but still with a high plasticity in food habits. This may be a result of the low density in red fox populations in the study area, probably due to hunting.

Not surprisingly, also the exotic species have a different trophic niche composition when compared with their native range diet. The common genet, in its northern distribution areas of southern France, has been described as feeding mostly on mammals (Cugnasse and Riols 1984, Livet and Roeder 1987, Lodé et al. 1991), whereas in southern Mediterranean habitats, fruits also become an important food resource (Palomares and Delibes 1991, Rosalino and Santos-Reis 2002). Studies in Algeria, which is part of the common genet native distribution area, have shown that arthropods are one of the most important prey items (Hamdine et al. 1993, Virgós et al. 1999). Our re- sults show a local adaptation to the consumption of fruits, easily available to this species in the study area. Furthermore, the genet appears to be the most generalist of the four studied species, with a higher degree of opportunistic feeding behaviour, as demonstrated by the relation availability-consumption. The few available studies on diet of the Egyptian mongoose have shown a higher consumption of mammals, and a significant intake of reptiles (Delibes 1976, Palomares and Delibes 1991, S. Domingos unpubl.). Delibes (1976) reviewed the mongoose diet in several areas of its distribution, denoting this predator's preference for mammals and reptiles. Our results corroborate a higher preference for mammals, also including insects and fruits.

The observed pattern of plasticity in both native and exotic species in shifting and broadening their food niche may be a response to fluctuations in resources availability characteristic of Mediterranean environments. Virgós and Casanovas (1999) demonstrated that Mediterranean landscapes are poor habitats for Eurasian badgers due to their less abundant and fluctuating food resources. However, we believe that this concept can be extended to other carnivores inhabiting these landscapes, such as the four species studied herein. Assuming that animals' energetic expenditures and requirements are similar to other areas of their distribution range, Mediterranean populations have to feed upon available resources and become more omnivorous in order to subsist. Hence, there seems to be a compromise between low energetic expenditure in food acquisition in exchange for low energetic input, resulting in an opportunistic behaviour in food gathering. In addition, resource fluctuation in Mediterranean habitats creates a unique situation not found in other north European areas. These resources are not consistently found throughout the year, thus creating a need to switch to other food items temporarily available. Virgós et al. (1999) defined this pattern - addition of alternative food items into carnivore diet (arthropods, reptiles and amphibians) - as "mediterraneity", which in our case can also be extended to fruits.

Other adaptations to seasonal resource availability have lead to the consumption of non-traditional prey items, such as the introduced Louisiana crayfish. This is an exotic species from northeast Mexico and south central United States, which have invaded Portuguese streams since 1970s (Correia 2002). Despite having negative effects on riverine 
and aquatic communities (Correia 2002), the introduced crayfish acts as a staple and complementary food item during the hot and dry summer months, for both native and exotic carnivore species. Our results show that this prey is particularly important to the common genet, a situation that has not been yet described by other authors (Correia 2001). Furthermore, this may also be an example of exotic species facilitating other exotic species persistence.

European carnivore community trophic niche composition and overlap has been shown to be conservative and similar across species. The majority of the community comparisons have addressed the overlap between martens and the red fox, describing their feeding habits as opportunistic, with availability playing a major role in prey selection patterns (Goszczynski 1986, Storch et al. 1990, Serrafini and Lovari 1993, Lanszki et al. 1999, Padial et al. 2002). Our results corroborate the high degree of overlap between these two species found in other Mediterranean areas (Serafini and Lovari 1993). Due to the restricted geographic distribution of common genet and Egyptian mongoose in Europe, no studies to date have addressed the interaction of these four species. Only Carvalho and Gomes (2004) have addressed the diet of four carnivore species: stone marten, common genet, wild cat, Felis silvestris, and the red fox in a temperate Atlantic Eurosiberian region of northern Iberian Peninsula. Our results show that the exotic species are sharing the same resources to a greater extent than the native species, which is particularly notable. First, exotics have a broader trophic niche than natives. These species are using all the available resources by utilizing less exploited niche components, as demonstrated by their most generalist status, when compared to natives. Secondly, the combined effect of differences in body size and species locomotory activity adds to this divergence; being predictable that stone marten and genets would be closer, and Egyptian mongoose and red foxes most similar. In fact, we found higher similarities between the pair of arboreal species (genet and stone marten) and the pair of terrestrial species (red fox and Egyptian mongoose). The morphologically arboreal-adapted species, especially using trees for foraging and resting (Santos-Reis et al. 2004), would be better adapted for eating fruits more often, which was reflected in their diet. In contrast, morphologically terrestrial-adapted species would be more apt to take advantage of different food resources, such as reptiles and coleopterans. However, fallen fruits are also available to terrestrial species as reflected by their diet patterns.

Finally, the cumulative effects of the presence of other carnivore species and the absence of these long-established exotic species can also alter the dynamics of the guild and its interactions with prey. In higher latitudes, the composition of the carnivore guild is different from the Mediterranean habitats, with the presence of larger predators (e.g. European lynx, and racoon) and other mesocarnivores (e.g. pine marten, mink). These differences in predator communities may enhance competition for limited re- sources, influencing the number of prey available to smaller carnivores, such as the stone marten. Waechter (1975) and Delibes (1978) described sinantropic behaviour (occupation of human impacted areas) of stone martens in areas of sympatry with pine martens, Martes martes. However, one can argue that the presence of the genet may have the same effect as the pine marten in restricting prey availability to stone marten. To our knowledge, only one previous study addressed the potential competition between these two species (Santos-Reis et al. 2004), where stone martens and genets share spatial, temporal and food resources; resource availability does not seem to be limiting, but further clarification is necessary.

The competitive exclusion principle states that two ecologically similar species cannot coexist. Our results indicate that the four studied mesocarnivores have a strong overlap in their diet composition. This result may indicate that the trophic niche partition may only play an important role in the coexistence of these species, if considered at the prey species level. Other factors should be considered when analysing niche partitioning strategies. Are the species partitioning time, space or territory? Santos-Reis et al. (2004) found that a high overlap in home-ranges is found between stone martens and genets, as well as similar habitat and time use strategies. Domingos (unpubl.) and our own observations have shown that Egyptian mongooses may reshape their realized niche by having diurnal activities. In addition, red foxes have been observed in the morning and at dusk, maybe indicating an alternative strategy. Therefore, the mesocarnivore community niche structure in the Mediterranean landscapes of southern Portugal may not only be defined by trophic partitioning but also by the combination of other strategies. Future research should clarify this multiple strategy in niche differentiation that may shed light in exotic species acclimation mechanisms.

Acknowledgements - We would like to thank Luís Miguel Rosalino and Marina Rodrigues for their help during fieldwork. The European Union PRODED Program, the Centre for Environmental Biology of the Univ. of Lisbon and the FCT Project PRAXIS/PCNA/BIA/105/96 granted funding and logistic support.

\section{References}

Alegre, J., Hernandez, A., Purroy, F. J. et al. 1991. Dieta otoñoinvernal de la garduña, Martes foina (Erxleben, 1777), en un habitat rural de Leon (España). - Ecologia 5: 265-273.

Artois, M., Andral, L., Dubreuil, M. et al. 1982. Contribution a l'étude de la biologie du renard roux (Vulpes vulpes). - Rev. Méd. Vét. 133: 249-262.

Artois, M. 1989. Le renard roux (Vulpes vulpes Linnaeus, 1758). Encyclopédie des carnivores de France. - Société Française pour l'Étude et la Protéction des Mammiféres 3: 1-90.

Borralho, R., Rego, F., Palomares, F. et al. 1996. The distribution of the Egyptian mongoose Herpestes ichneumon (L.) in Portugal. - Mammal Rev. 26: 1-8. 
Brom, T. G. 1986. Microscopic identification of feather-remains after collisions between birds and aircraft. - Bijdragen tot de Dierkunde 56: 181-204.

Calzada, J. 2002. Genetta genetta, Gineta. - In: Palomo, J. L. and Gisbert, J. (eds), Atlas de los Mamíferos Terrestres de EspañaMadrid, Spain: Dirección General de Conservación de la Naturaleza-SECEM-SECEMU, pp. 290-293.

Calviño, F., Canals, J. L., Bas, S. et al. 1984. Regimen alimenticio del zorro (Vulpes vulpes L.) en Galicia, Noroeste de la Peninsula Ibérica. - Bol. Est. Central Ecol. 13: 83-89.

Carvalho, J. C. and Gomes, P. 2004. Feeding resource partitioning among four sympatric carnivores in the Peneda-Gerês National Park (Portugal). - J. Zool. Lond. 263: 275-283.

Chinery, M. 1986. Insects of Britain and western Europe, Collins Pocket Guide. - Domino Books Ltd, Jersey, UK.

Correia, A. M. 2001. Seasonal and interspecific evaluation of the predation by mammals and birds on the introduced red swamp crayfish Procambarus clarkii (Crustacea, Cambaridae) in a freshwater marsh (Portugal). - J. Zool. Lond. 255: 533-541.

Correia, A. M. 2002. Niche breadth and trophic diversity: feeding behaviour of the red swamp crayfish (Procambarus clarkii) towards environmental availability of aquatic macroinvertebrates in a rice field (Portugal). - Acta Oecol. 23: 421-429.

Cugnasse, J. M. and Riols, C. 1984. Contribution a la connaissance de l'écologie de la genette (Genetta genetta L.) dans quelques départements du sud de la France. - Faun. Sauv. 1: 25-55.

Debrot, S., Fivaz, G., Mermod, C. et al. 1982. Atlas des poils de Mammiferes d'Éurope. Neuchâtel, France. - Univ. de Neuchâtel.

Delibes, M. 1976. Datos sobre la alimentacion del meloncillo, Herpestes ichneumon widdringtoni Gray, 1842, en España. Säugetierkundliche Mitteilungen 24: 38-42.

Delibes, M. 1978. Feeding habits of the stone marten, Martes foina (Erxleben, 1777) in northern Burgos, Spain. - Z . Säugetierkunde. 43: 282-288.

Delibes, M. 1982. Notas sobre la distribución pasada y actual del meloncillo Herpestes ichneumon (L.) en la Peninsula Iberica. Doñana. - Acta Vertebr. 9: 341-352.

Dobson, M. 1998. Mammal distributions in the western Mediterranean: the role of human intervention. - Mammal Rev. 28: $77-88$.

Gama, M. M. 1957. Mamíferos de Portugal (Chaves para a sua determinação). - Separata de Memórias e Estudos do Museu Zoológico da Universidade de Coimbra 246: 1-246.

Goszcyzñski, J. 1974. Studies on the food of red foxes. - Acta Theriol. 1: 1-18.

Goszczyñski, J. 1986. Diet of foxes and martens in Central Poland. - Acta Theriol. 31: 491-506.

Jedrzejewska, B. and Jedrzejewski, W. 1998. Predation in vertebrate communities: the Bialowieza primeval forest as a case study. Ecological Studies Vol. 135. - Springer.

Hamdine, W., Thévenot, M., Sellami, M. et al. 1993. Régime alimentaire de la genette (Genetta genetta) dans le Parc National du Djurjura, Alérie. - Mammalia 57: 9-18.

Hardin, G. 1960. The competitive exclusion principle. - Science 131: 1292-1297.

Keller, A. 1978. Détermination des mammiféres de la Suisse par leur pelage: I- Talpidae et Soricidae. - Rév. Suisse Zool. 85: 758-761.
Keller, A. 1980. Détermination des mammiféres de la Suisse par leur pelage: II- Diagnose des familles. III- Lagomorpha, Rodentia (partim). - Rév. Suisse Zool. 87: 781-796.

Keller, A. 1981. Détermination des mammiféres de la Suisse par leur pelage: IV- Cricetidae et Muridae. - Rév. Suisse Zool. 88: 463-473.

Kendall, K. C., Metzgar, L. H., Patterson, D. A. et al. 1994. Power of sign surveys to monitor population trends. - Ecol. Appl. 2: 422-430.

Kolar, C. S. and Lodge, D. M. 2001. Progress in invasion biology: predicting invaders. - Trends Ecol. Evol. 16: 199-204.

Krebs, C. J. 1989. Ecological methodology. - Harper Collins Publishers.

Lanszki, J., Körmendi, S., Hancz, C. et al. 1999. Feeding habits and trophic niche overlap in a Carnivora community of Hungary. - Acta Theriol. 44: 429-442.

Levins, R. 1968. Evolution in changing environments. - Princeton Univ. Press.

Libois, R. and Waechter, A. 1991. La Fouine (Martes foina Erxleben, 1777). - Encyclopédie des carnivores de France. Société Française pour l'Étude et la Protéction des Mammiféres 10: $1-53$.

Livet, F. and Roeder, J. J. 1987. La genette (Genetta genetta, Linnaeus, 1758). - Encyclopédie des carnivores de France. Société Française pour l'Étude et la Protéction des Mammiféres 16: 1-33.

Lodé, T., Lechat, I. and Le Jacques, D. 1991. Le regime alimentaire de la genette en limit nord-ouest de son aire de répartition. - Rev. d'Ecol. Terre Vie 46: 339-348.

Madureira, M. L. and Ramalhinho, M. G. 1981. Notas sobre a distribuição, diagnose e ecologia dos Insectívora e Rodentia portugueses. - Arq. Mus. Bocage, série A, 1: 165-263.

Palomares, F. 2002. Herpestes ichneumon, Meloncillo. - In: Palomo, J. L. and Gisbert, J. (eds), Atlas de los Mamíferos Terrestres de España. Madrid, Spain: Dirección General de Conservación de la Naturaleza-SECEM-SECEMU, pp. 286-289.

Palomares, F. and Delibes, M. 1991. Alimentacion del meloncillo Herpestes ichneumon y de la gineta Genetta genetta en la reserva biológica de Doñana, S.O. de la Peninsula Iberica. - Acta Vertebr. 18: 5-20.

Padial, J. M., Ávial, E. and Gil-Sánchez, J. M. 2002. Feeding habits and overlap among red fox (Vulpes vulpes) and stone marten (Martes foina) in two Mediterranean mountain habitats. - Mamm. Biol. 67: 137-146.

Primack, R. B. 1998. Essentials of conservation biology. - Sinauer Ass.

Rasmussen, A. M. and Madsen, A. B. 1985. The diet of the stone marten Martes foina in Denmark. - Nat. Jutlandica 8: 141144.

Ray, J. C. and Sunquist, M. E. 2001. Trophic relations in a community of African rainforest carnivores. - Oecologia 127: 395-408.

Romanowski, J. and Lesínski, G. 1991. A note on the diet of stone marten in south-eastern Romania. - Acta Theriol. 36: 201-204.

Rosalino, L. M. and Santos-Reis, M. 2002. Feeding habits of the common genet Genetta genetta (Carnivora: Viverridae) in a semi-natural landscape of central Portugal. - Mammalia 66:195-205.

Rosalino, L. M., Santos, M. J., Domingos, S. et al. 2005. Population structure and body size of sympatric carnivores in a 
Mediterranean landscape of SW Portugal. - Rev. Biol. (Lisboa) 23:135-146.

Ruiz-Olmo, J. and Palazon, S. 1993. Diet of the stone marten (Martes foina Erxeleben, 1777) in the northeastern Spain. Doñana Acta Vertebr. 20: 59-67.

Sadlier, L. M. J., Webbon, C. C., Baker, P. J. et al. 2004. Methods of monitoring red foxes Vulpes vulpes and badgers Meles meles: are field signs the answer? - Mammal Rev. 34: 75-98.

Santos-Reis, M. and Correia, A. I. (eds) 1999. Caracterização da flora e fauna do montado da Herdade da Ribeira Abaixo (Grândola, Baixo Alentejo). - Univ. de Lisboa.

Santos-Reis, M., Rosalino, L. M. and Rodrigues, M. 1999. Lagomorfos, carnívoros e artiodáctilos (Mamíferos). - In: SantosReis, M. and Correia, A.I. (eds), Caracterização da flora e fauna do montado da Herdade da Ribeira Abaixo (Grândola, Baixo Alentejo). Univ. de Lisboa, pp. 249-262.

Santos-Reis, M., Santos, M. J., Lourenço, S. et al. 2004. Relationships between stone martens, genets and cork oak woodlands in Portugal. - In: Harrison, D. J., Fuller, A. K. and Proulx, G. (eds), Marten and fishers (Martes) in human-altered environments: an international perspective. Springer, pp. 147-172.
Serafini, P. and Lovari, S. 1993. Food habits and trophic niche overlap of the red fox and stone marten in a Mediterranean rural area. - Acta Theriol. 38: 233-244.

Smallwood, K. S. 1994. Site invisibility by exotic birds and mammals. - Biol. Conserv. 69: 251-259.

Storch, I., Lindström, E. and Jounge, J. 1990. Diet and habitat selection of the pine marten in relation to competition with the red fox. - Acta Theriol. 35:311-320.

Sutherland, W. J. 1998. Conservation science and action. Blackwell.

Virgós, E. and Casanovas, J. G. 1999. Environmental constraints at the edge of a species distribution, the Eurasian badger $(\mathrm{Me}$ les meles L.): a biogeographic approach. - J. Biogeogr. 26: 559-564.

Virgós, E., Llorente, M. and Cortés, Y. 1999. Geographical variation in genet (Genetta genetta L.) diet: a literature review. Mammal Rev. 29: 119-128.

Waechter, A. 1975. Ecólogie de la fouine en Alsace. - Rev. d'Ecol. 29: 399-457.

Zar, J. H. (ed.) 1999. Biostatistical analysis, (2nd ed.) - Prentice Hall, Inc. 